Historic, archived document

Do not assume content reflects current scientific knowledge, policies, or practices. 
, 


\section{A Catalog of \\ Japanese Rose Flowering Cherries Chinese Flowering Crabs Persian Double Flowering Peach Flowering Plum Dogwood and others from the}

GARDEN NURSERIES

NARBERTH

PENNSYLVANIA

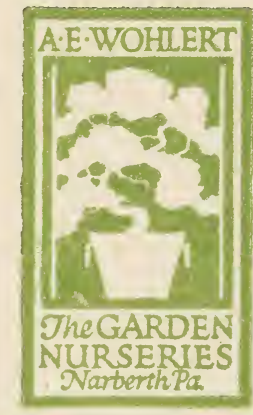

COPYRIGHT, A. E. WOHLERT, 1923 


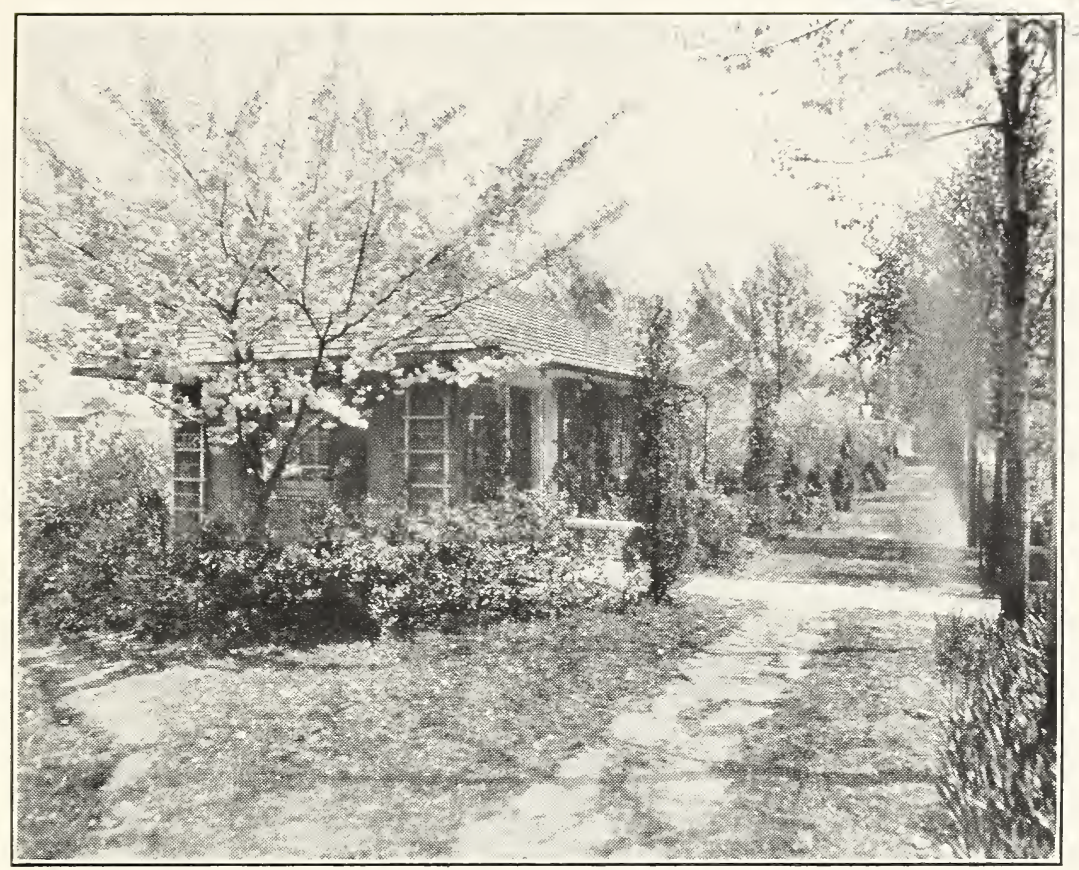

\section{THE GARDEN NURSERIES}

OCATED on the Montgomery Pike at Narberth, the Garden Nurseries are most easily accessible by auto for anyone living on the Main Line, or in an adjacent locality.

The most enjoyable time to visit the Garden Nurseries is naturally when the flowering cherries, almonds, crab apples and plums are in full bloom. That also is a good time to purchase plants of this type, as they can be transplanted while blooming, from pots.

Our passenger station is Narberth, on the Main Line of the Pennsylvania Railroad. As it is an eight-block walk, anyone wishing to save time or carry away any small plants, should take one of the taxicabs standing at the station.

The Garden Nurseries are open the year 'round to visitors. They contain the greatest variety of oriental flowering trees grown commercially in America. 


\title{
JAPANESE ROSE FLOWERING CHERRIES
}

MONG men, the samurai ; among flowers, the sakura," is a familiar saying, which well expresses the patriotic pride with which this gay, flashy flower is regarded in Japan. The sentiment is also conveyed in the following lines by one of the national poets:

\author{
"Shikishima no \\ Yamato gokoro wo \\ Hitotowaba \\ Asahi ni niwou \\ Yamazakura bana."
}

"Should you ask me what is the true patriotic spirit, I answer: it is the scent of the mountain cherry tree in the morning air."

Japan has had its wild cherry since the memory of man, though today it is found in abundance only in the woods of the Northern Island, Yeddo, where the Aino aborigines use its bark for many purposes. So far as the records show, however, it was not until the time of Richiu, Emperor of the Fifth Century, that it received royal notice. And it was a later Emperor, Shomu, of the eighth century who immortalized it in a verse to his favorite consort, Komio Kogo:

"This gatbered cherry branch can scarce convey $A$ fancy of the blossom-laden tree,

Blooming in sunlight; could I show it thee,

Thoughts of its beauty would drive sleep away."

To satisfy the curiosity of the ladies of his court, the Emperor ordered cherry trees to be planted near the Palace at Nara, and afterwards the custom was continued at each succeeding capital. In and near the modern capital, Tokyo, are several spots renowned for their show of cherry trees, originally brought from Yoshino, and from the banks of the Sakura river in the province of Hitachi. Cherry viewing became a popular amusement in Yeddo towards the latter half of the seventeenth century. All classes of the people, from the two-sworded samurai to the small tradesmen and menials, participated in the enjoyment. The green sward beneath the cherry trees was crowded with merry picnic parties of all classes, screened off with low colored curtains. One favorite resort, called Asukayama, at $\mathrm{Oji}$, is often spoken of as the new Yoshino. It is a high, grassy bluff, overlooking 
an extensive plain on one side, and sloping down to the village on the other. The eminence forms a $\mathrm{p}$ a r $\mathrm{k}$ of cherry $t \mathrm{r}$ e e $\mathrm{s}$ extending down the precipitous sides of the bank, so that the pedestrian sees the pinky white bloss o $\mathrm{m} \mathrm{s}$ against the blue sky above him, and below the pearly gray of the blossoms in $t h \mathrm{e}$ $\mathrm{sh}$ a dow s of the cliff.

(1) OJOCHIN ZAKURA. "Paper Lantern." M e a n s big lantern. Zakura means cherry. Should bloom light colors, big and d o u ble. (Large, white, semi-double, prolific). Very $\mathrm{s}$ y $\mathrm{mmet}$ r c a 1 growth.

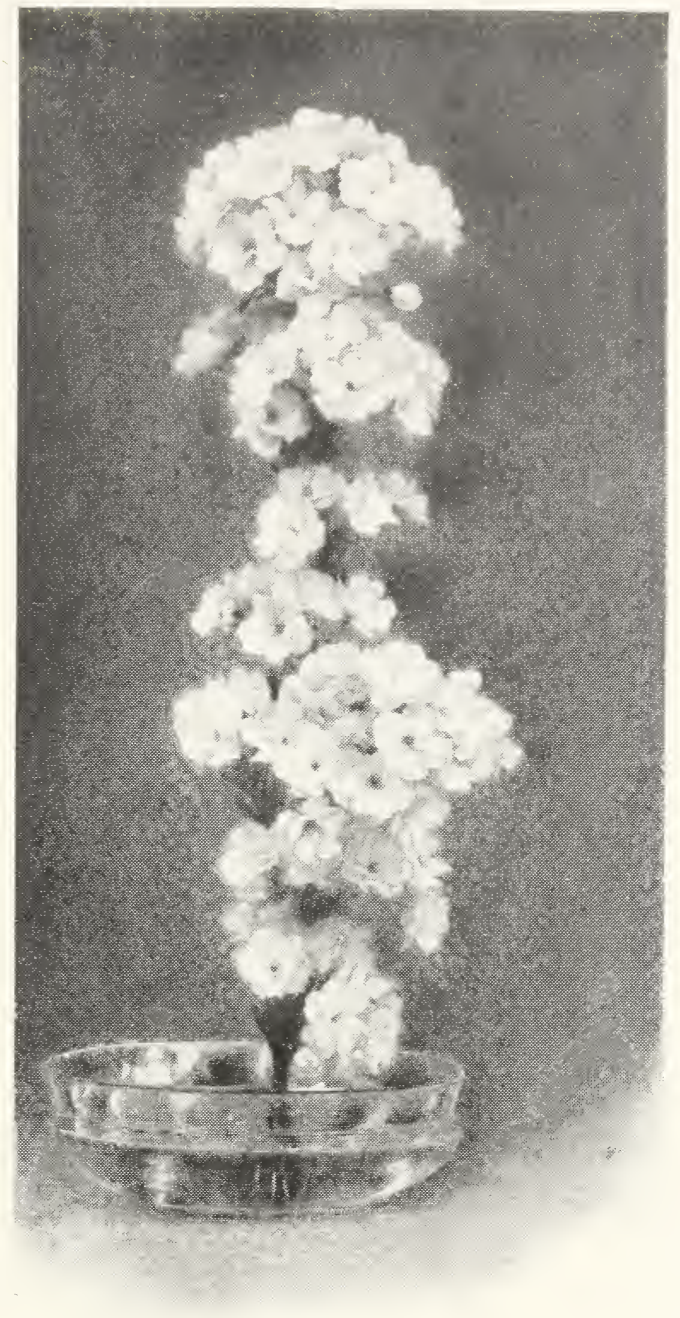

(2) KO - FUGEN - ZAKURA. "Pink Saint" is the Cherry shown in the second decoration. Its full name is Ko-Fugenzo. Ko means pink. Fugenzo means saint's appearance. It should bloom pink, big double flowers. Very striking; by many thought the best of all. We sell more of this variety than any other.

(4). AMA-NO-GAWA-ZAKURA. Means "River of Heaven." (Milky Way). Upright like poplar. Should bloom double pink. (Most desirable variety, new; grows 
like a lombardy poplar, a splendid show in the Spring). Effective as formal tree. Blush pink, fragrant, very choice. First decoration pictures this sort.

(7) HI-ZAKURA. Flowers are the same type as the picture shown on this page, but much deeper in color. Its full name is Kan Hi-zakura. Kan means cold. Hi-zakura means deep pink cherry. It blooms in early part of year while weather is still cold. (A very vigorous growing, upright variety. The buds are crimson; the flowers are red, fading into old rose. A most unusual color in Flowering Cherries-very rare and desirable).

This is a vigorous growing variety and the earliest of the dark red Japanese Cherries, as the name indicates. In Japan, it is the most popular of the rose-colored vari-

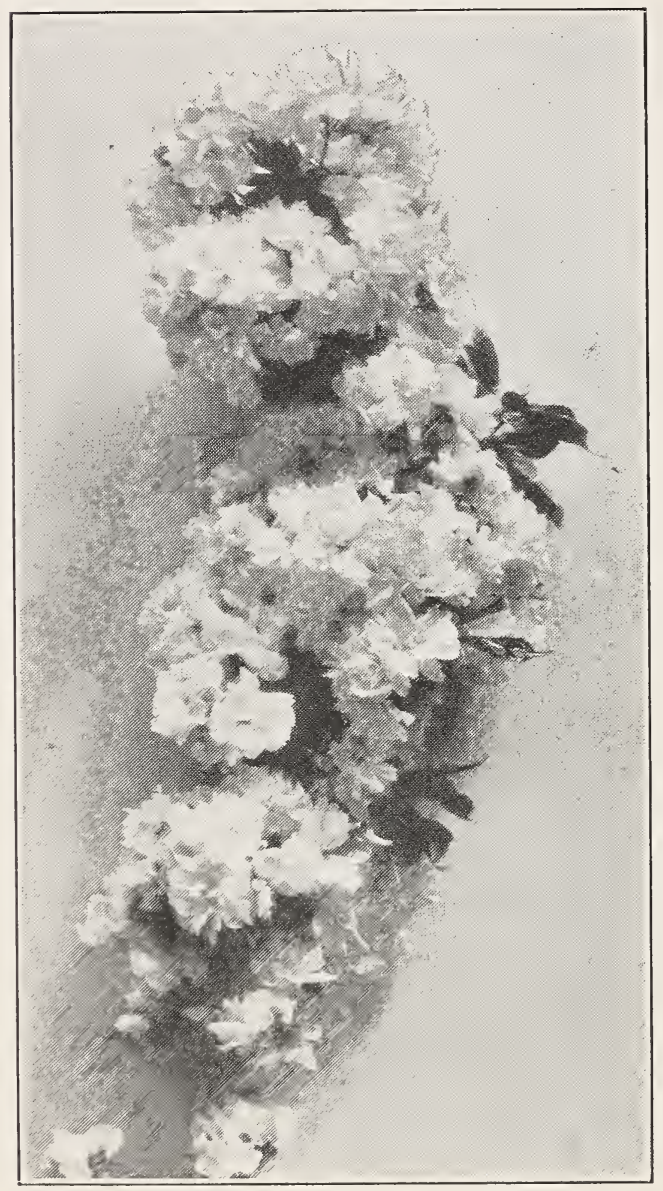
eties. We like it very much on account of its symmetrical growth.

MI - KURUMA $G A$ E S H I $Z$ A $K$ U $R$ A. $\mathrm{Mi}$ when it is written before rum means certain respect. Kuruma means wheel, car or Riksha. Gaeshi means turn back, so it must mean that the flower is so beautiful that people cannot help to turn back to look at it again. (Semi-double brilliant pink flowers of medium size). Very prolific.

(10). "ROSEA." A double rose-colored form of the Flowering Cherry. Very full, globular pendulous flowers from three to five 


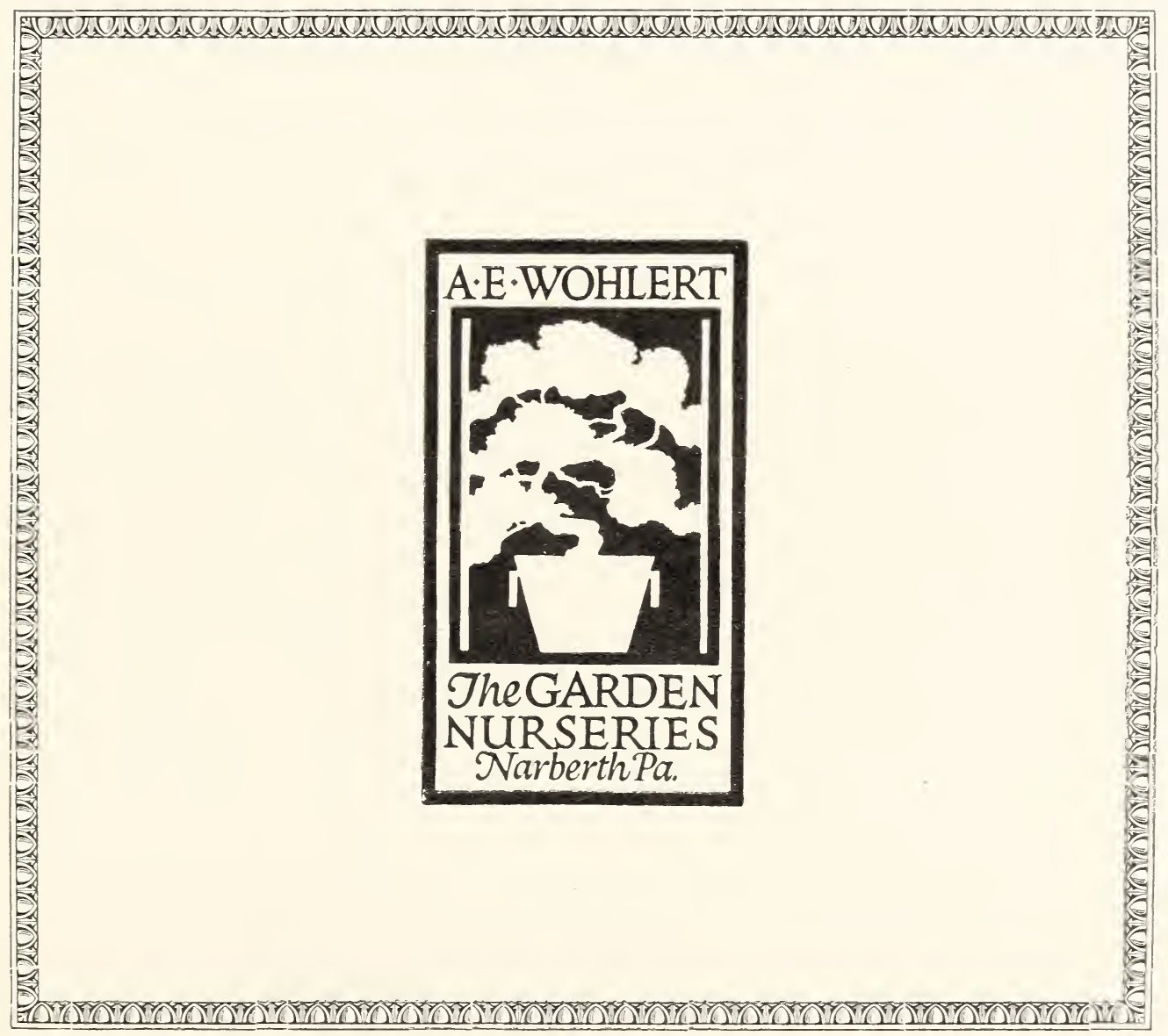




\section{Chinese Flowering Crab "Grafts"}

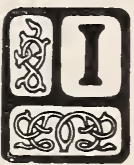

$\mathrm{N}$ order to afford an opportunity for all to get a collection of my beautiful Chinese Flowering Crabapples at a nominal price, I have decided to offer this year young "grafts"; that is, freshly grafted trees with roots and all complete ready to plant, in collections of 4 and 10 sorts. Do not let this chance slip by if you want any of the trees for a try-out, as I may not again present this offer. I do it now only as an experiment to learn how the public will accept the idea.

The young "grafts" may be planted in beds, in the vegetable garden or in the flower beds, anywhere; the soil packed about the root and left alone; nature does the rest. Only, watch that poultry, dogs or children do not hurt the tender shoots. Permit only one or two sprouts to grow from the scion or top, and none from the root, as these would be suckers or "wild." Two years later the trees may be planted in the permanent location.

Four young trees may be had at $\$ \mathbf{1 . 5 0}$, or ten trees for $\$ \mathbf{3 . 0 0}$ postpaid. You may select the varieties, or I will do it for you. I will send you the sorts that, in my judgment, are best, although from the point of view of some authorities they may all be equally valuable.

Malus Atropurpurea-Red flowers; vigorous habit; flowers are of good size and color.

“ Baccata-Single. pink buds, opening white The most fragant variety of all crabs in cultivation. A fine fruit for fragrant jelly. This sort does not bloom profusely before the tree is at least five years old, but then makes up for lost time.

“ Baccata (Tsen Mei)-Very fragrant like the above type, but the flowers are larger and more beautiful. The fragrant fruit makes fine jelly.

“ Bechtels (Pocahontas)-The flowers are a most delightfully soft pink and very large. It is the latest to bloom, and dwarf in habit. Very fragrant.

“ Coronarius - Single pink flowers; fragrant; tall growing. 
Malus Floribunda (Fung Shing)-Single, pink flowers; spreading habit; prolific flowering; large crop of small fruit.

“Atrosanguinea (Ming Shing)-Brilliant red, the most showy of the Crabs. This in my judgment is easily the most showy of the early flowering Crab. It is not fragrant, but the small single flowers are so abundant that they clothe the naked branches absolutely and the show is not obscured by foliage. A most attractive specimen tree on a lawn. Blooms the first year after planting.

“ Nietzwetzkyana-Red flowers, leaves, bark, sap, and all. Very showy; rather vigorous; open habit.

"Parkmanii-Semi-double, rose, rather dwarf in habit, but one of the most beautiful and desirable.

" Scheideckerii-Double pink. A very prolific flowering sort; large double deep rose flowers, crimson buds, flowers in bottle brush formation.

“Wah Mee-Brilliant double apple blossoms and abundant fruit for jelly.

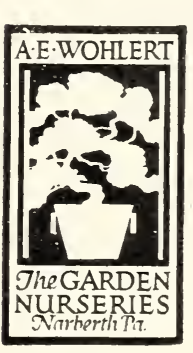

The fruits of all the varieties make superior jelly. Wash the fruit, remove the stems and boil the entire fruit in usual way.

\section{Trees for $\$ 1.50 ; 10$ Trees for $\$ 3.00$. Postpaid.}

We also have 500 Malus Sargentii to offer, 15 to 24 inches high, at 75 cents each. This is a beautiful dwarf spreading bush suitable for small gardens, formal gardens and rockeries.

\section{A. E. WOHLERT, Narberth (Montgomery $)$ Penna.}




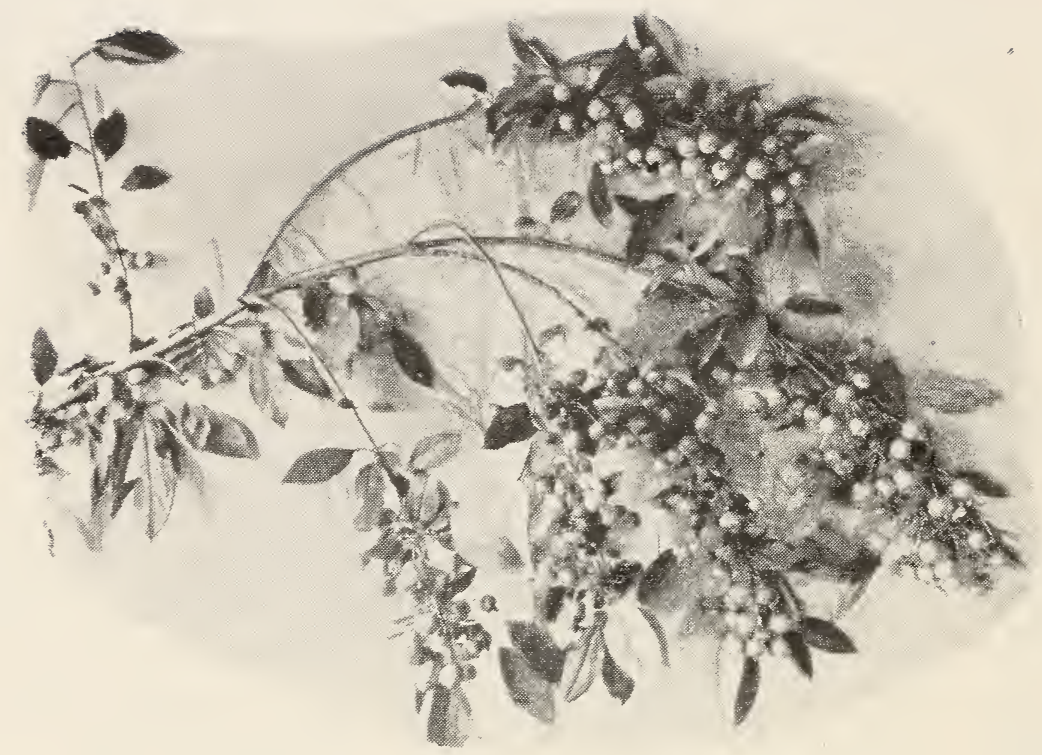

A Fruiting Branch of one of the Chinese Flowering Crabs. The Fruits are the Size of Cherries; at least twice as many Flowers in the Spring as you see Fruit in the Fall. 


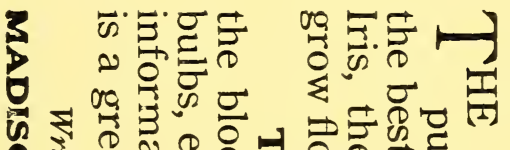

을

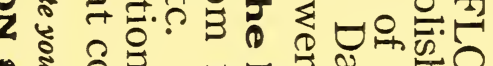

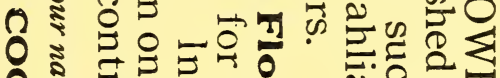

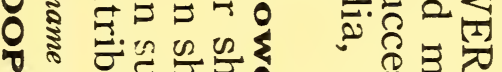

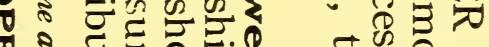

事

\%

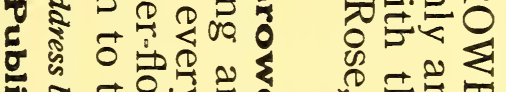

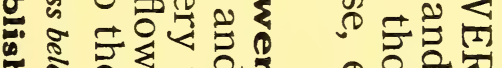

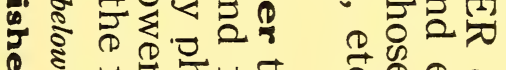

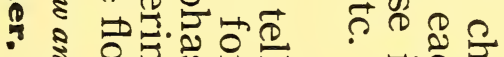

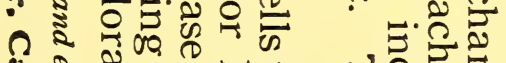

\&

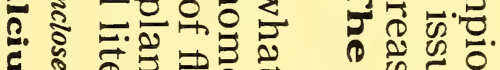

ร

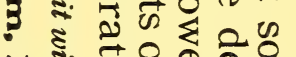

थ गु

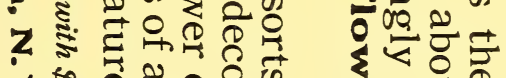

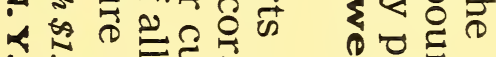

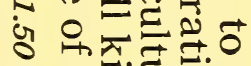

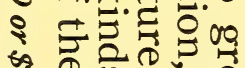

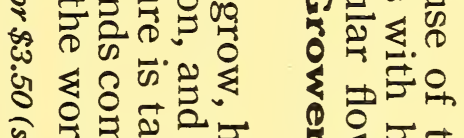

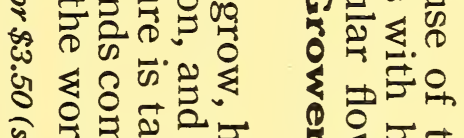

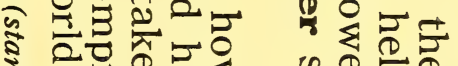

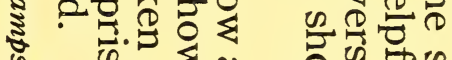

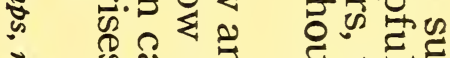

ङ

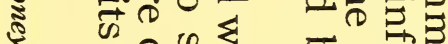

₹ ร유류

3. कर

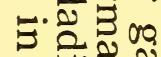

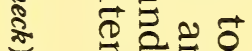

इ 施政

\% क थ

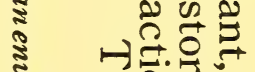

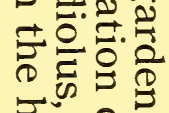

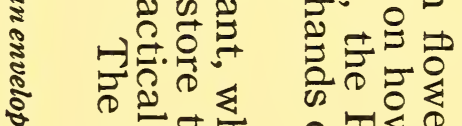

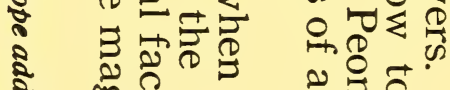

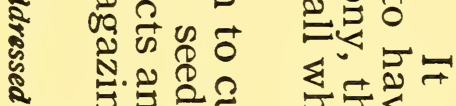

3 政总

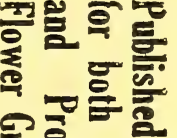

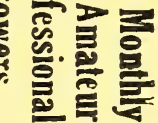

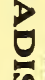

2 0 (a)

o

$0^{-1}$

政

: $\leq<$

\%

告

.

? $\begin{array}{ll}3 \\ 2 \\ 3 \\ 3\end{array}$

2

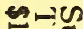

두ㅇㅡㅜ

$\checkmark$ :

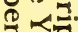

$<B$

궁

so

is 



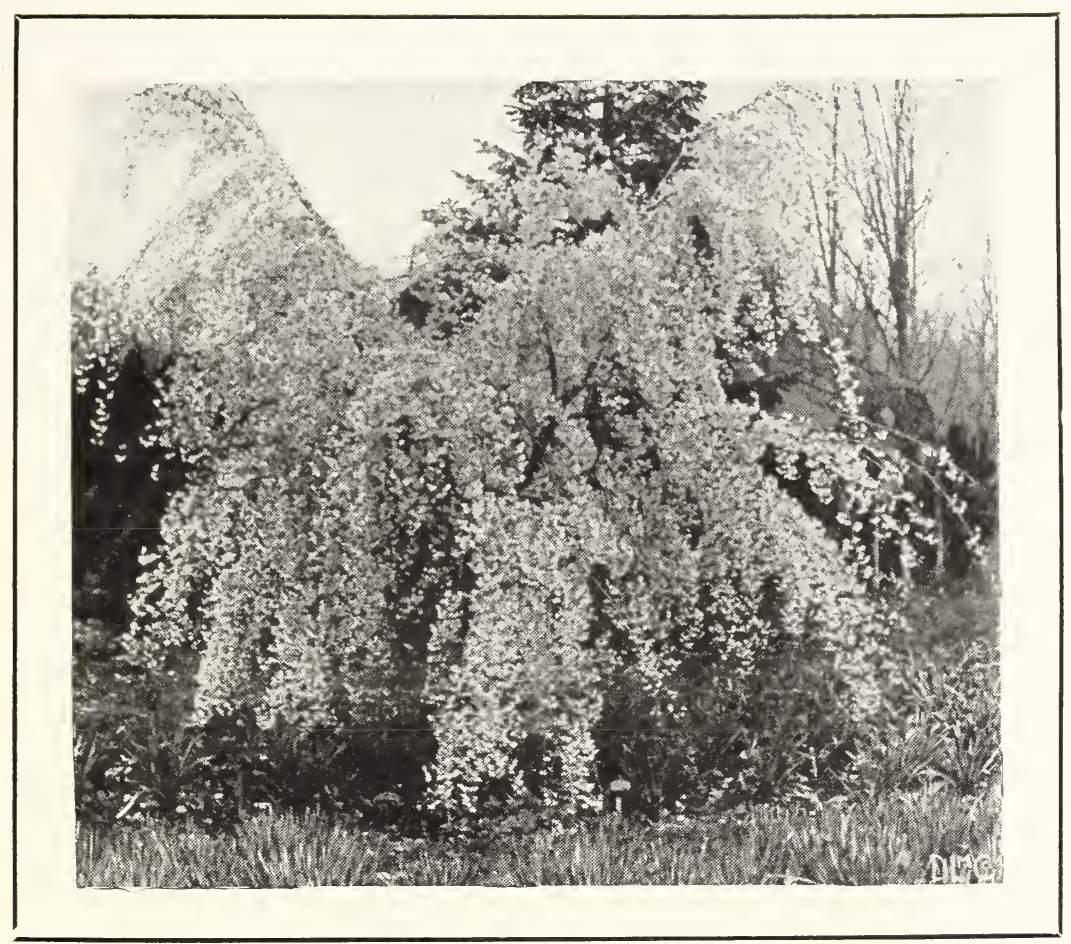

No. 11 Shidare-Higan-Zakura

in a cluster. Cheerful, soft pink, offering a very striking contrast to the majority of the Japanese Cherries. It appears to be, when in bloom, the most popular of all the varieties, coming, as it does frequently, ahead of the other varieties, it has but little competition at that time, and this, may in part, account for its popularity. Speciments of this sort should be in every collection.

(11). SHIDARE - HIGAN - ZAKURA. "Weeping Cherry." (Cerasus). Prunus. Subhirtella Pendula. Shidare means branches bent downward something like willow. Higan means when day and night are the same length in Springtime, so it should bloom when day and night are same length. (Deep pink, single, early, weeping; one of the most prolific varieties). Earliest of all.

The Weeping Cherry is without question the most attractive weeping tree known to horticulturists. It is in habit something like the Weeping Beech. The foliage 
is as good as any of the well known weeping trees, Birch, Beech or Willow, and in addition to that the bright flowers cover the tree by the thousands; in large trees they number hundreds of thousands, making a gorgeous mass of pink, impossible to reproduce in colored print, but fairly well shown on the cover of this book.

In the old temple grove, now a public park, at Uyeno, there are a number of fine trees of the single early blossoming kind, Higan-Zalkura, among which are some magnificent specimens of the weeping cherry. This latter species has pendant branches, drooping like the willow, and bears single pink flowers, but rarely fruit; and in this respect it is an exception to the general rule, that the trees of single blossom bear fruit whilst those of double blossom are fruitless.

(14). SEKIZAN - ZAKURA. "Sacred Gate." Seki means gate, such as joined one territory to another at olden times of Japan. Zan means mountain. It w a s operated something like a toll gate is in this country, but not to collect money, but to keep out undesirables. It should bear deep pink big double flowers. A vigorous grower.

The flower in appearance is very similar to $\mathrm{Hi}-\mathrm{Z}$ akura. The one distinct difference is two green carpels in the center of the flower, which it also shares with our No. 2. The buds are very darls crimson, opening up deep rose. It is a very scarce variety.

Our descriptions are credited largely to a Japanese catalogue, and the translations by a Japanese residert of Philadelphia.

Kofugen-Zakura, in fuil bloom, is shown on page 3 , beside our office.

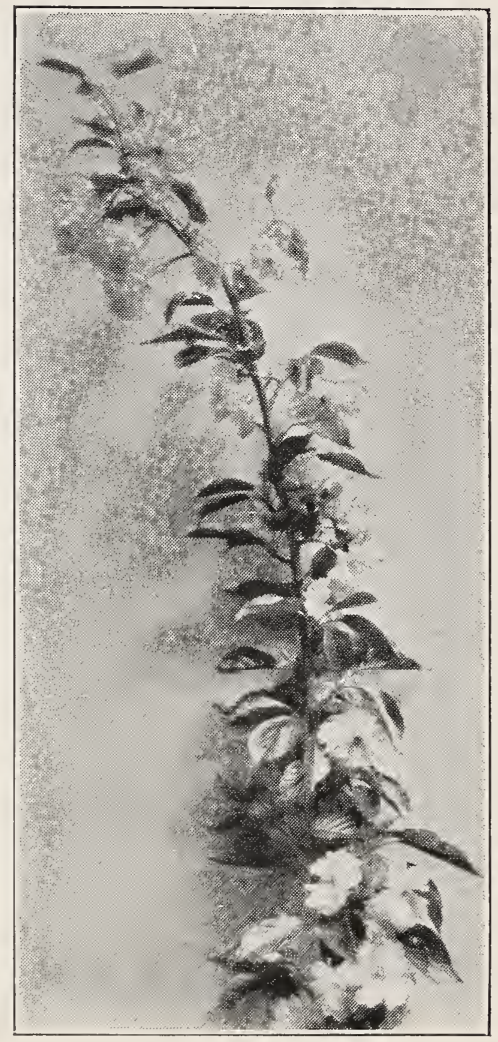


ROSE FLOWERING CHERRIES IN STOCK

March 1st, 1923

SHIDARE, WEEPING

Pyramids, single, deep pink flowers

\begin{tabular}{|c|c|c|}
\hline Size & Quantity & Price Each \\
\hline & feet. & $\$ 5.00$ \\
\hline & feet. & 6.0 \\
\hline $5-6$ & feet. & 7.50 \\
\hline- & feet. & 10.00 \\
\hline-10 & feet. & 15.00 \\
\hline & $\ldots \ldots 7$ & 20.00 \\
\hline 2 & 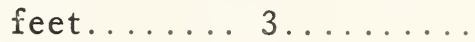 & 25.0 \\
\hline
\end{tabular}

SHIDARE, WEEPING

Standards, single, deep pink flowers

\begin{tabular}{|c|c|c|}
\hline ize & Quantity & Price Each \\
\hline yea & .50 . & $\$ 6.00$ \\
\hline & & \\
\hline yea & & 10.00 \\
\hline & 14 & 15 \\
\hline a & & 20 \\
\hline & .21 & 25.00 \\
\hline
\end{tabular}

AMANOGAWA

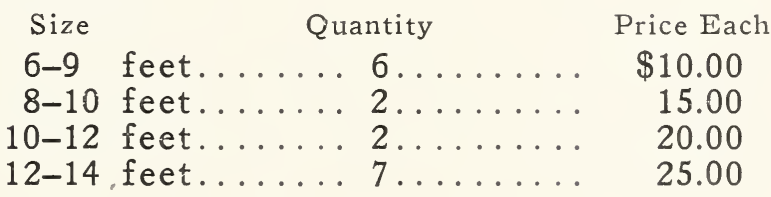

ROSEA, MIKURUMA GAESHI

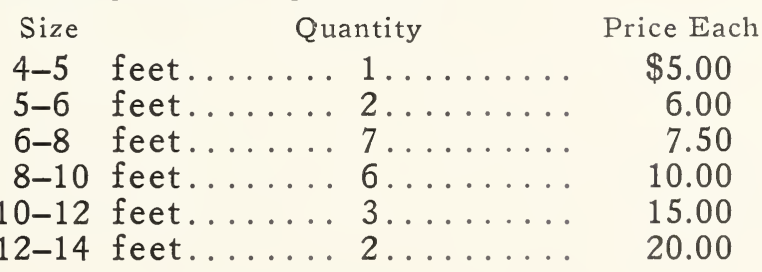

ROSEA, MIKURUMA GAESHI

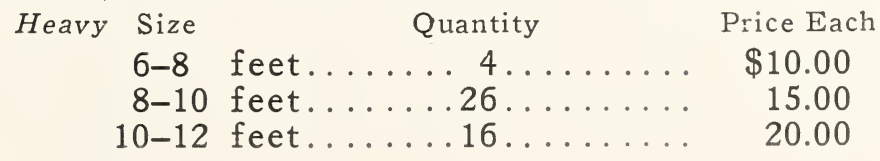


KOFUGEN, SIEBOLDI

\begin{tabular}{|c|c|c|}
\hline Size & Quantity & Price Each \\
\hline & feet. & $\$ 5.0$ \\
\hline & fee & 4 \\
\hline $6-\varepsilon=1-\varepsilon$ & feet & 8.0 \\
\hline & feet.... & 12.0 \\
\hline
\end{tabular}

KOFUGEN, SIEBOLDI

$$
\begin{aligned}
& \text { Heavy Size Quantity Price Each } \\
& \text { 6-8 feet......15 ...... } \$ 10.00 \\
& 8-10 \text { feet......34....... } 15.00 \\
& 10-12 \text { feet...... 1...... } 20.00
\end{aligned}
$$

SEKIZAN

$$
\begin{aligned}
& \text { Size Quantity Price Each } \\
& \text { 5-6 feet...... 1...... } \$ 7.50 \\
& \text { 6-8 feet...... 4....... } 10.00 \\
& 8-10 \text { feet...... 5 . . . . . } 15.00 \\
& 10-12 \text { feet...... 3...... } 20.00
\end{aligned}
$$

HIZAKURA

$$
\begin{aligned}
& \text { Size Quantity Price Each } \\
& \text { 6-8 feet......6. 6..... } \$ 10.00 \\
& \text { 8-10 feet...... 2...... } 15.00 \\
& 10-12 \text { feet...... 2...... } 20.00
\end{aligned}
$$

HIZAKURA

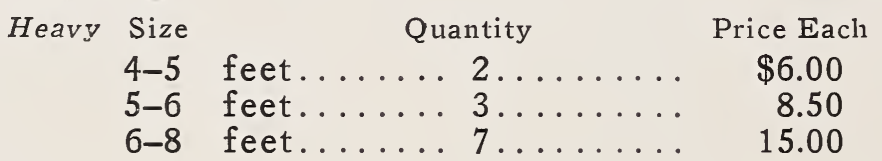

OJOCHIN, No. 1

$$
\begin{aligned}
& \text { Size Quantity Price Each } \\
& 2 \mathrm{I} / 2-23 / 4^{\prime \prime} \text { caliper . 3 . . . . . . } \$ 15.00 \\
& 3-3 \mathrm{I} / 4^{\prime \prime} \text { caliper.. 7 ........ } 20.00 \\
& 3 \mathrm{I} / 2^{\prime \prime} \text { caliper..... 1...... } 25.00 \\
& 4 \mathrm{I} / 2 \text { " caliper..... 1....... } 30.00
\end{aligned}
$$

BENI-HIGAN

$$
\begin{array}{cccc}
\text { Size } & \multicolumn{2}{c}{\text { Quantity }} & \text { Price Each } \\
5-6 & \text { feet....... } 1 \ldots \ldots \ldots \ldots & \$ 12.00 \\
10-12 & \text { feet...... } & 1 \ldots \ldots \ldots & 15.00
\end{array}
$$

CERASUS NEW RED

$$
\begin{aligned}
& \text { Size Quantity Price Each } \\
& \text { 6-8 feet...... 3 . . . . . } \$ 10.00 \\
& 8-10 \text { feet...... 4....... } 15.00
\end{aligned}
$$


SARGENTII (Single, deep red)

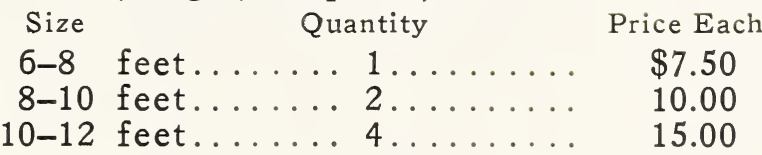

ROSEA, DUTCH

$$
\begin{aligned}
& \text { Size Quantity Price Each } \\
& \text { 8-10 feet...... 1 ...... \$ } \$ 15.00 \\
& 10-12 \text { feet...... 1...... } 20.00
\end{aligned}
$$

KOFUGEN, SIEBOLDI

$$
\begin{aligned}
& \text { Size Quantity Price Each } \\
& 2 \mathrm{I} / 2^{\prime \prime} \text { caliper.... 4 . . . . . . } \$ 25.00 \\
& 23 / 4^{\prime \prime} \text { caliper..... 4 . . . . . . } 25.00 \\
& 3^{\prime \prime} \text { caliper..... 1....... } 25.00 \\
& 3 \mathrm{r} / 2^{\prime \prime} \text { caliper..... 2....... } 35.00 \\
& 4 \mathrm{I} / 4 \text { " caliper..... 1....... } 35.00 \\
& 41 / 2 \text { " caliper..... 3....... } 35.00 \\
& 5 " \text { caliper..... 5....... } 50.00 \\
& 5 \mathrm{I} / \mathrm{z}^{\prime \prime} \text { caliper..... 3....... } 50.00 \\
& 53 / 4 \text { " caliper..... 4........ } 50.00 \\
& \text { 6" caliper..... 1...... } 50.00
\end{aligned}
$$

We also have 100 to 150 trees grown in pots that range from 5 to 8 feet in height

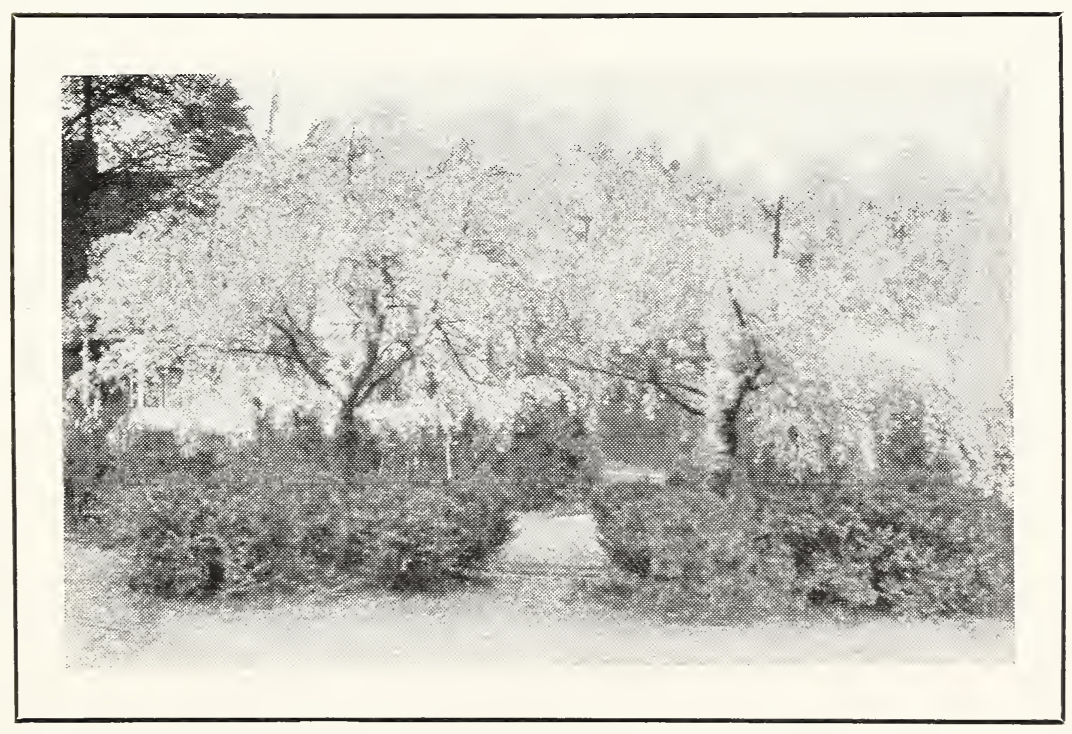

A Pair of Weeping Cherries at an Entrance 


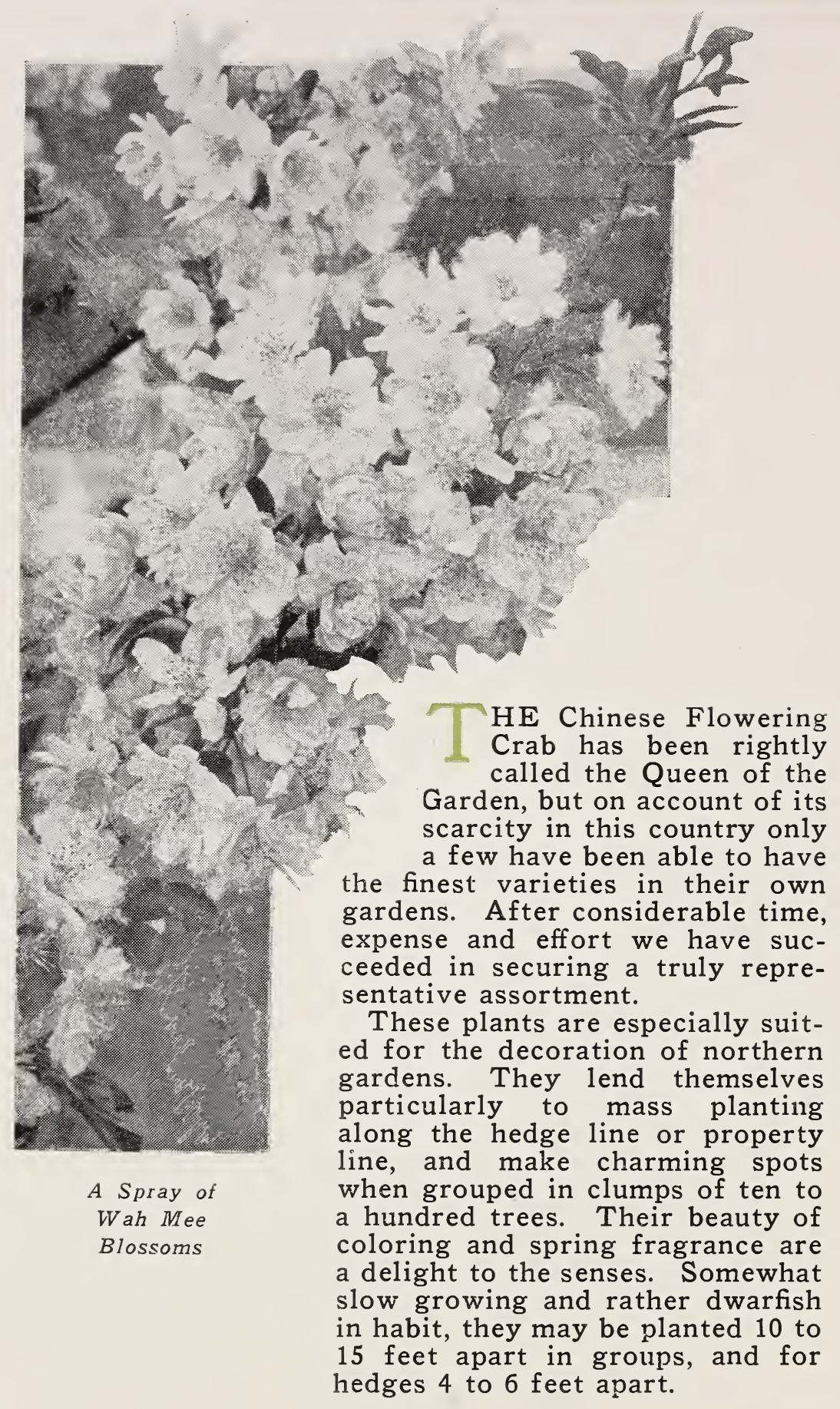




\section{DOUBLE FLOWERING CHINESE CRAB APPLES}

I ING SHING. Stars of Heaven. For landscape effect this variety (Fung Shing and Wah Mee) is possibly the ultimate. Ming Shing, translated the Stars of Heaven (by Lady Tsen Mei), is the most striking in general effect; the tree or bush is of irregular growth, though of a very vigorous habit when young. Every branch is literally covered by the crimson or red flowers; not a leaf in sight when the crimson buds appear, they unfold as a red, a gorgeous velvety red, and when the sun shines through the branches almost a scarlet is suggested-a very unusual effect-very Oriental in its regal splendor.

As the tree grows older it becomes more irregular in its habit of growth, but very little is gained by pruning, save in the first few years. Ming Shing should be in every garden, and I am sure we shall be many years older before I can produce enough to meet the demand.

TSEN MEI. Spring Perfume. The wild form is quite abundant over the Chinese hills, filling the air with its delightful fragrance; the cultivated varieties are somewhat improved in form, but retain every breath of the delightful perfume of the original wild crab of China. The buds are red, the flowers white, in great umbels or clusters; individual flowers single, the snowy whiteness being very striking, and when the tree is in bloom a very charming sight. Once you have been within reach of Tsen Mei's charm the perfume exhaled will keep you spellbound for years and the memory never leave you.

Some forms will show a slight flush of color over the otherwise virgin white of the petals; most plants produce white bloom. The fruit is as large as a small plum, highly colored and fragrant. (Makes splendid jelly). Buds are pink or red.

WAH MEE. The Modest Maiden. Malus Scheideckerii. A wonderfully prolific small tree, in spring covered with a delightful mass of double flowers of a deep rose color. The habit of the tree is very branching, and the branches are ascending, somewhat perpendicular and covered with the charming flowers it lends itself particularly to use as cut bloom with no disadvantage to the tree, as it seems to be benefited by pruning while in bloom. Ping Fah and Wah Mee are both producers of an 


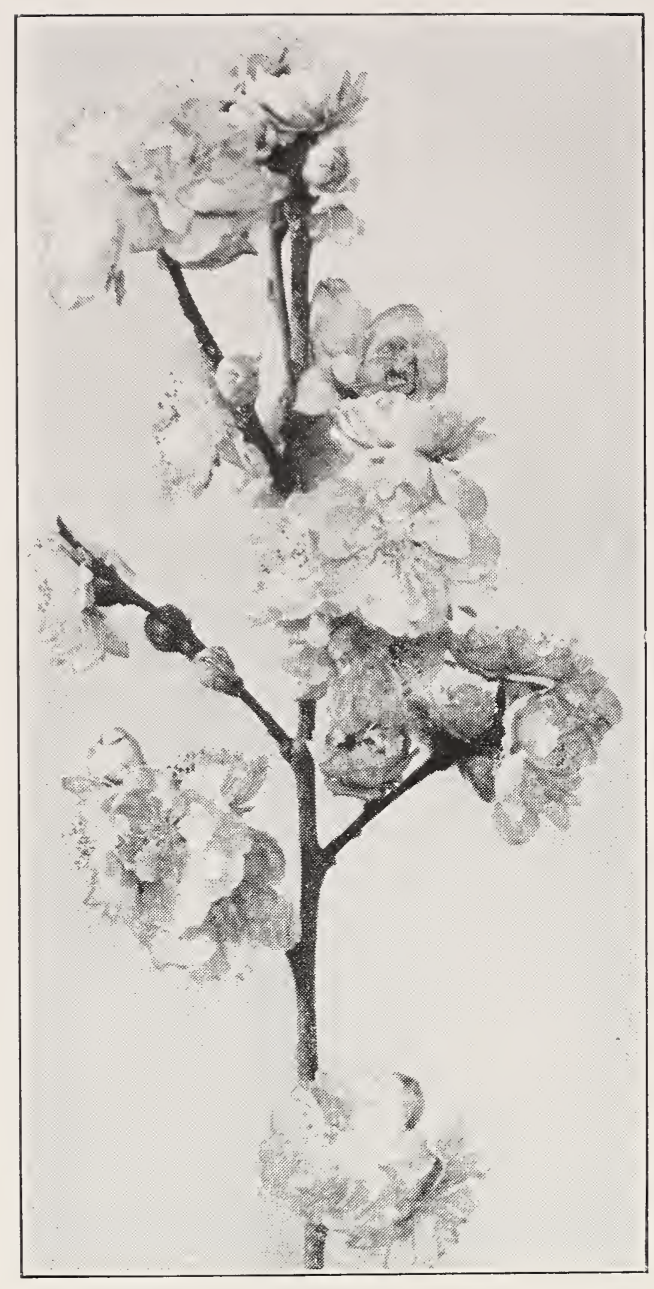

a bundance of cherry-like fruit, y e $110 \mathrm{w}$, red and orange, that makes the famous Chinese apple jelly so famed for its pleasing odor and flavor.

POCAHONTAS. Pyrus iœnsis, Bechtel's variety. This is a Native American apple, a double form of our wild crab. The flowers are a most delightfully soft pink and very large. As the picture indicates, the buds are perfectly globular, the flowers very full and in size quite a little larger than a silver dollar. Our illustration shows a trifle less than half life size. It is the latest to bloom in our collection, and the tree is in full leaf while in bloom while the Chinese varieties dis play their gorgeous flow-

ers on bare stems utterly void of foliage, and are for this reason more effective in the decorative scheme on the lawn. Many of our friends like this sort best, I think, for the reason that "Pocahontas" has no competition while in bloom-all the rest have passed several weeks earlier. Our native variety is also very fragrant, a delicate perfume of great charm, but not as distinguished as our Tsen Mei, which stands without a peer as the most fragrant flower of the spring garden.

As this is written while vegetation is still dormant the writer would say to all nurserymen and florists who expect to have trees to sell to lay in a stock of Bechtel's 


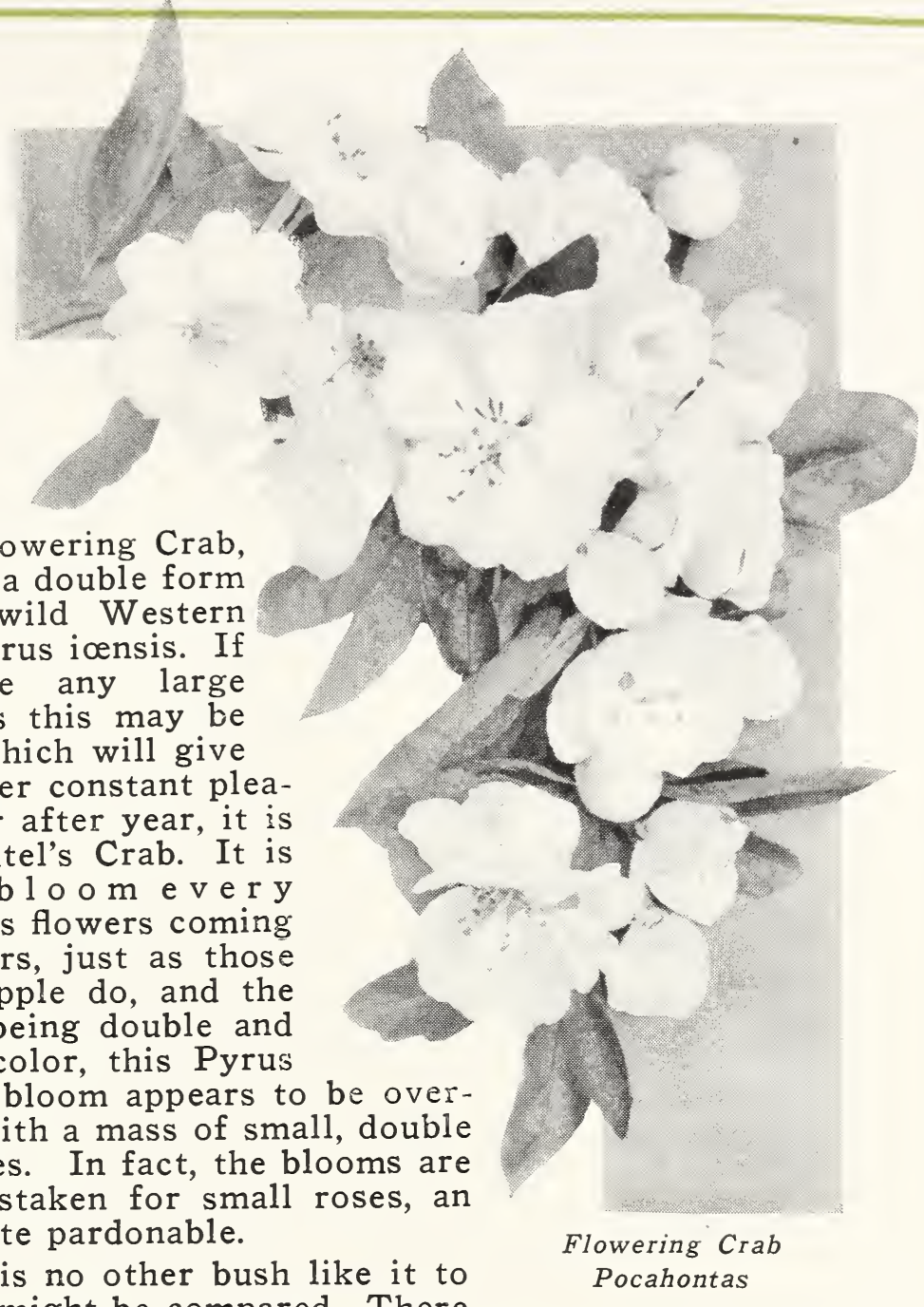

double flowering Crab, which is a double form of the wild Western Crab, Pyrus iœnsis. If there be any large shrub, as this may be called, which will give a customer constant pleasure year after year, it is the Bechtel's Crab. It is sure to bloom e very spring, its flowers coming in clusters, just as those of the apple do, and the flowers being double and pink in color, this Pyrus when in bloom appears to be overspread with a mass of small, double pink roses. In fact, the blooms are often mistaken for small roses, an error quite pardonable.

There is no other bush like it to which it might be compared. There are many small trees and bushes belonging to the rosaceous order, as this does, having flowers of like color and which are highly esteemed, but in the whole collection not one with the foliage and habit of this tree, and with such handsome double pink flowers.

When allowed to grow at will, starting in a good shape at first, Bechtel's double flowering Crab forms a well shaped, large bush, hardly a small tree, and it maintains this habit through life. Considering its great merit it is not as often seen as it deserves.-Florists' Exchange, April 7, 1917.

MALUS SARGENTI - Sargent's Flowering Crab. Dwarf spreading grower; flowers pure white; colored fruits; suitable for rockeries. 2 years $-\$ 2.00$ Each. 
PING FAH. Abundance of Joy. The flower in bud is coral red, opening to a full-blown gorgeous soft pink. The flowers are very large and come in such abundance as to envelop all the branches with the bright pink brilliant double blooms about the size of a 50-cent piece. The fruit is abundant and splendid for jelly, superior to the usual crab apple jelly.

GUI TOI. Dragon's Tears. This variety is, from point of grace, the most pleasing of all our Chinese flowering crab apples. The flowers are disposed on thin, red, wire-like stems that permit the semi-double, rosecolored flowers to droop most gracefully. The gathered branches are, even in the hand of the unskilled decorator, the most effective subject.our spring season affords for indoor embellishment. The Chinese Dragon is the embodiment of all the good spirits and forces in nature. Very properly have the Chinese named this wonderful flower for the Dragon's Tears.

The charm is not confined to the cut flowers for when this small tree is clothed in its rosy robe it is easily the most cherished subject in the garden.

A few old plants of this variety are found in and about Philadelphia; one very noted tree is on Corker Hill, in Merion, $\mathrm{Pa}$. Usually this Gui Toi is noted as a charming bush about four feet to six feet high at the most, but on the Weaver estate a plant has reached in fifty years the height of 16 feet.

FUNG SHING. Smile of a Star. Fung Shing opens out at nearly the same shade of pink as Ming Shing displays when full blown; the two varieties are very similar in habit of growth and blooming. Fung Shing is red in bud, opening a delightful pink, and after a display of bloom prolonged over three weeks, the petals fall and cover the lawn with a blanket of silvery pink.

PRICE LIST

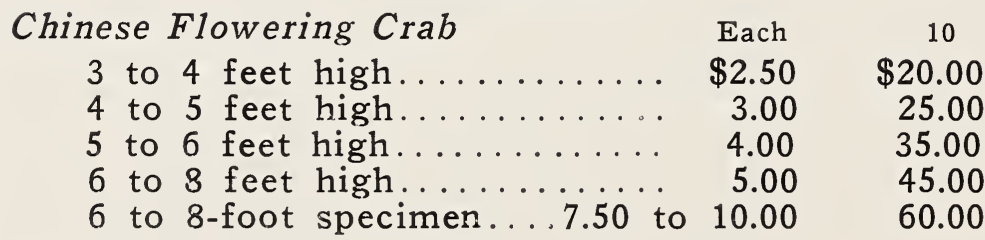

Gui Toi Variety

Each

2 to 3 feet high................ \$3.00

3 to 4 feet high................ 4.00 


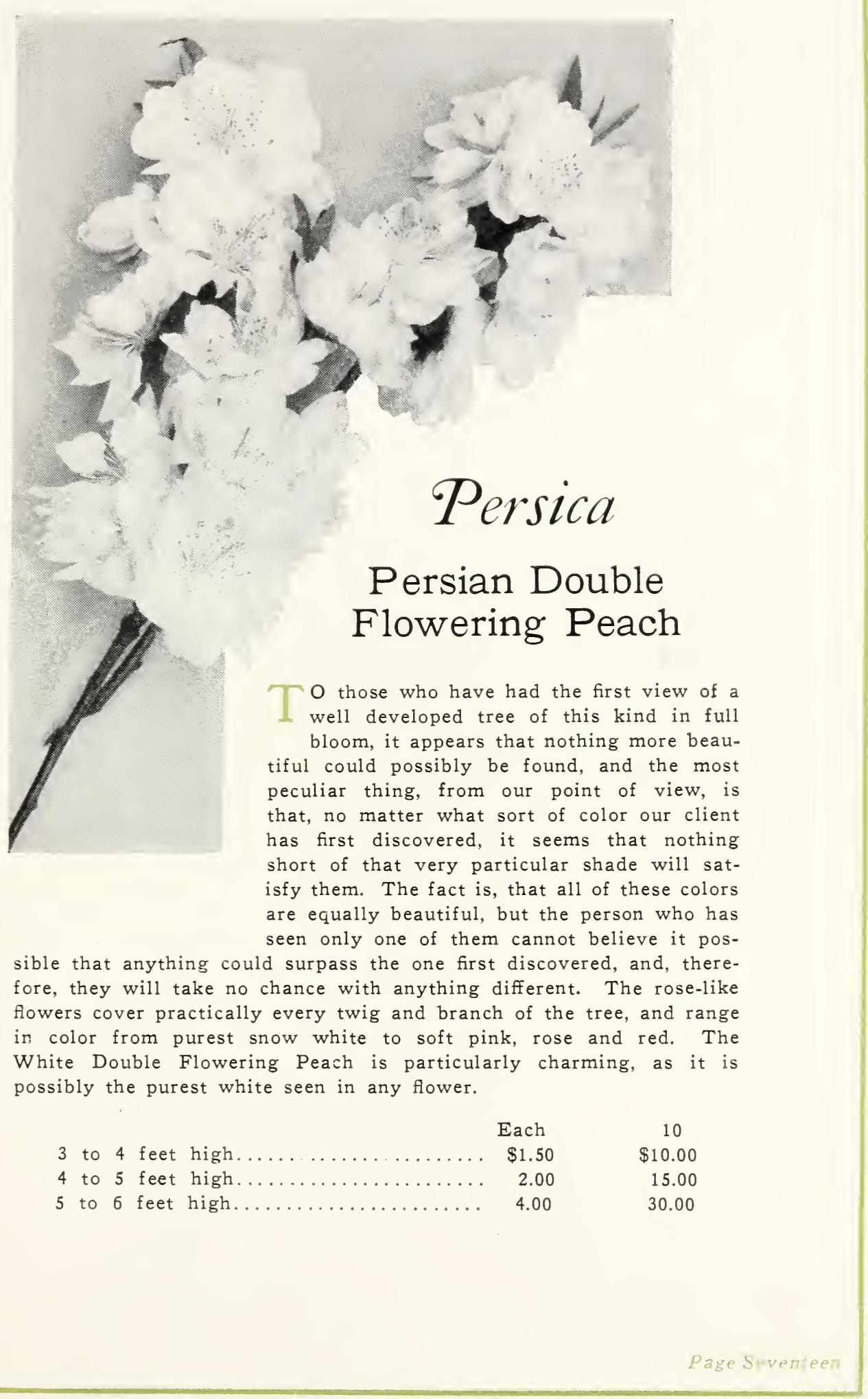




\section{CHINESE \& JAPANESE PLUMS}

\section{AND FLOWERING ALMOND}

D RUNUS TOMENTOSA (Chinese Flowering Plum). A most prolific flowering bush of dwarf habit, thickly studded with white flowers and later with purple or yellow plums about the size of Cherries. A most desirable acquisition in the garden.

PRUNUS TRILOBA (Japanese Flowering Plum). Exceedingly prolific in bloom; flowers mostly in advance of the leaves. Pink or rose colored, very double.

\begin{tabular}{|c|c|c|}
\hline & Each & 10 \\
\hline to $3 \mathrm{fe}$ & $\$ 1.50$ & $\$ 12.50$ \\
\hline to 4 & 2.00 & 15.00 \\
\hline
\end{tabular}

DWARF FLOWERING ALMOND, in Pink and White; a very desirable dwarf bush among the very earliest spring flowering shrubs.

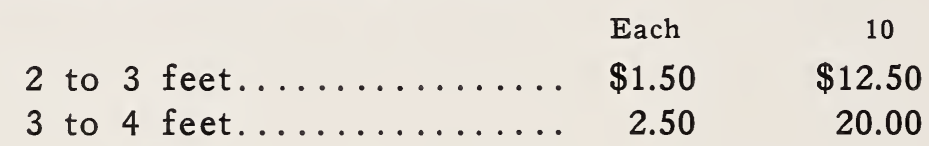

AZALEA HINODIGIRI ("Sunrise"). The brightest of the better known evergreen Azaleas from Japan; absolutely hardy from Hudson River south and grown into wonderful bushes of great size from Philadelphia south. The color is carmine pink when in bloom as no foliage is then in sight. In summer the foliage is a splendid green, turning copper color in the fall.

$\begin{array}{rrrr}6 \text { to } 8 \text {-inch } \operatorname{spread} \ldots \ldots \ldots \ldots \ldots & \begin{array}{r}\text { Each } \\ 81.50\end{array} & \begin{array}{r}\text { Dozen } \\ \$ 15.00\end{array} \\ 8 \text { to } 10 \text {-inch } \operatorname{spread} \ldots \ldots \ldots \ldots & 2.00 & 20.00 \\ 10 \text { to } 12 \text {-inch } \operatorname{spread} \ldots \ldots \ldots \ldots \ldots & 3.00 & 30.00\end{array}$




\section{CHINESE AND JAPANESE WISTARIA}

\section{WHITE AND PURPLE}

HINESE WISTARIA. Few plants are more attractive for pergola, porch trellis or gateway than the wistaria with its hanging cones of purple or white. While the purple adds a touch of color all its own, the white is the more fragrant and makes a fine display.

Pot-grown plants bloom the first season, the 6 and 8 -year-old plants having from 20 to 30 clusters of flowers.

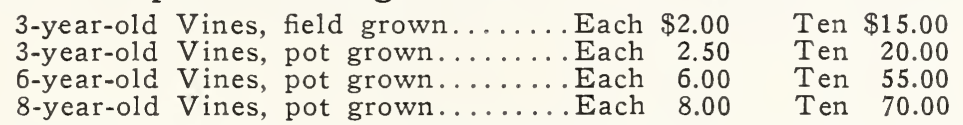
Growing these vines in pots causes stubby growth, but many flowers. The pot-grown vines may be planted outdoors as vines.

JAPANESE WISTARIA (Multijuga). This has the same general appearance as the Chinese, but the clusters are much longer, with individual flowers farther apart. It comes in purple and white. Priced as the Chinese.

JAPAN JUDAS TREE, or "Red Bud," an ornamental dwarf bush, very similar to our native tree, more compact and free blooming very early in spring.

2 to 3 feet high...................................... $\$ 1.50$

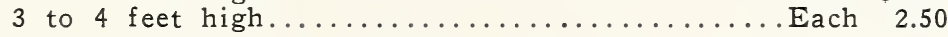

EUONIMUS VEGETA (Evergreen Bittersweet). The best hardy evergreen vine known, imported from Japan. More hardy than English Ivy. Just as green in winter, and in addition is covered with scarlet fruit that persists all winter.

Plants Each $\$ .75$ Ten $\$ 6.00$

FLOWERING HAWTHORNE. The three sorts we offer are garden varieties of the English Hawthorne. The improved forms we offer are double flowering and make beautiful and unusual lawn specimens and may well be lised in a grouping with Oriental Flowering Trees. They lend themselves particularly well to shearing or pruning, if this is thought desirable. The flowers are double and produced in umbels. The three varieties are Double White, Pink and Scarlet.

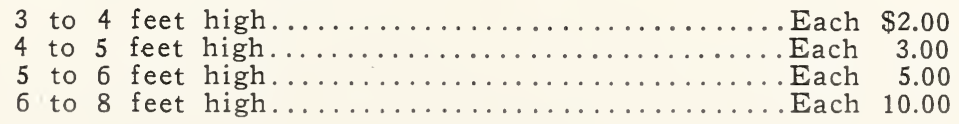



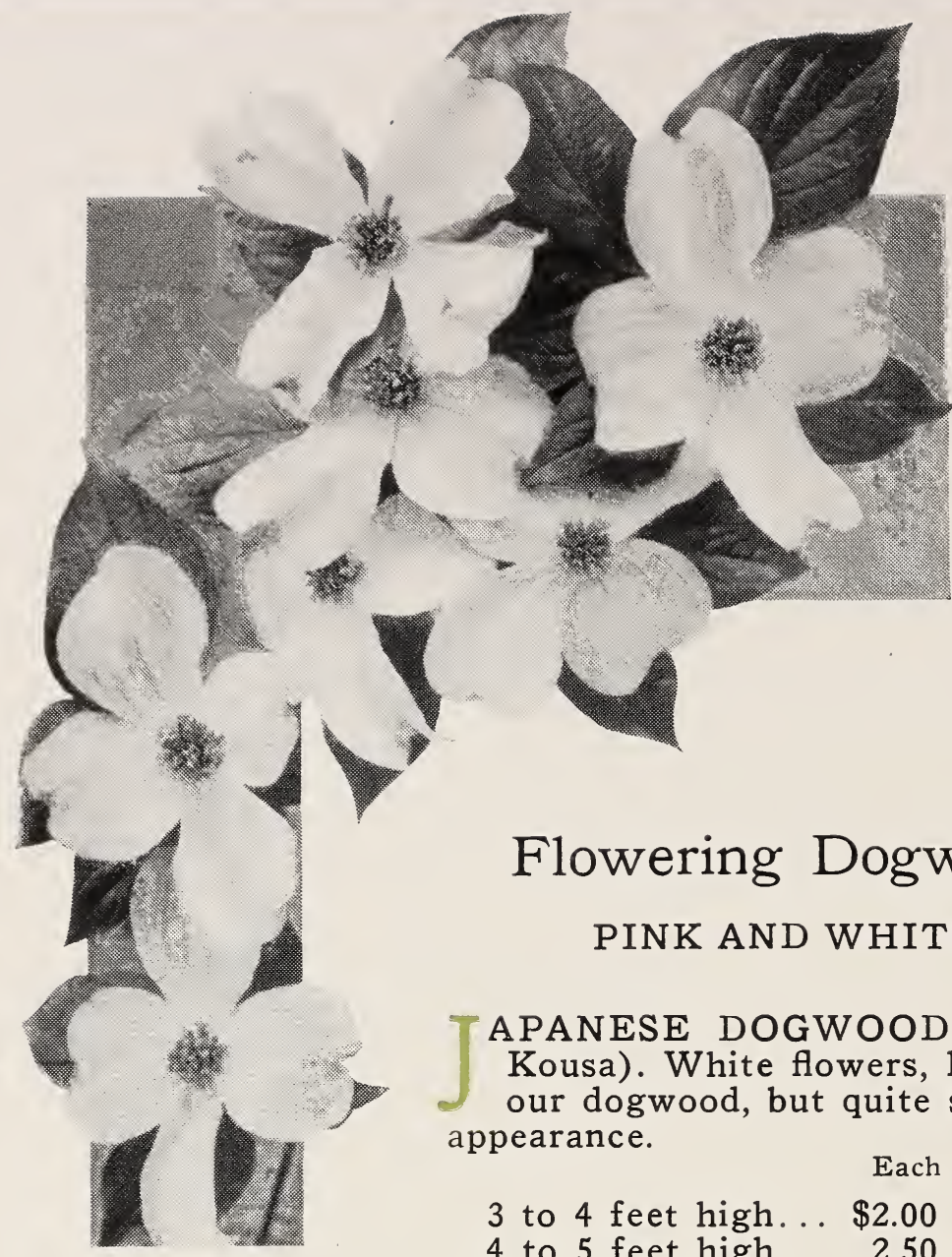

\title{
Flowering Dogwood
}

\author{
PINK AND WHITE
}

TAPANESE DOGWOOD (Cornus Kousa). White flowers, later than our dogwood, but quite similar in appearance.

$$
\text { Each } 10
$$

3 to 4 feet high... $\$ 2.00 \$ \$ 18.00$

4 to 5 feet high... $2.50 \quad 20.00$

AMERICAN DOGWOOD. "The Gem of the Forest." Always a joy in the garden or on the lawn, one of the most symmetrical small trees in cultivation. It comes in white, the wild type, and pink or red, a cultivated form.

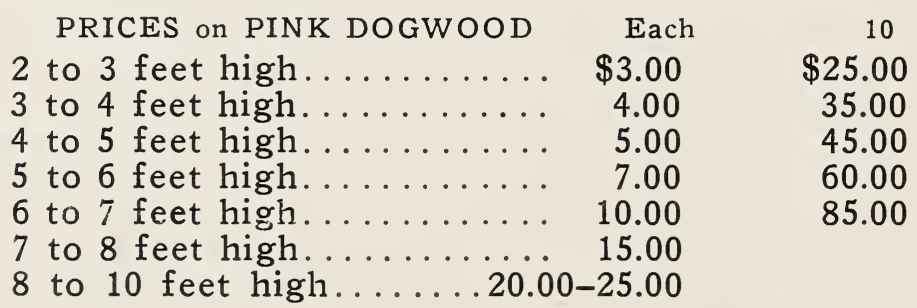

White Dogwood cost one-half of the above prices 


\section{HARDY PHLOX}

NE of the very best perennials; a continued succession of bloom from June until frost, if planted in fertile soil and watered during dry periods.

ALBION. Pure white, with a faint red eye.

BACCHANTE. Tyian-rose, with a crimson carmine eye.

B. COMTE. Brilliant rich French-purple.

BARON VAN DEDEM. Brilliant cochineal-red, with salmon shadings.

BEACON. Brilliant cherry-red.

CHAMPS ELYSEE. A bright rose-magenta; very effective.

CREPUSCULE. White with delicate mauve suffusion and rosypurple eye.

FRAU ANTON BUCHNER. The largest flowering pure white variety.

GLOW. A bright rich carmine with salmon suffusion, blood-red eye.

HENRY MURGER. White with crimson-carmine center.

JEANNE D'ARC. A good late flowering pure white.

MISS LINGARD. Early white, very popular.

MME. PAUL DUTRIE. Delicate lilac-rose, in tone like a soft pink Orchid; flowers large and borne in large panicles.

PROF. VIRCHOW. Bright carmine, overlaid with orange-scarlet.

RHEINLANDER. A most beautiful salmon-pink, with flowers and trusses of immense size.

RIVERTON JEWELL. A lovely mauve-rose illuminated by a brilliant carmine-red eye.

VON HOCHBERG. A beautiful rich purple, the very best in its class.

W. C. EGAN. One of the best, a pleasing soft pink with large bright solferino-red eye.

WIDAR. Light, reddish violet, with a very large white center, which intensifies and illuminates the color.

Extra large plants, from 4-inch pots or field, dependent upon the season.

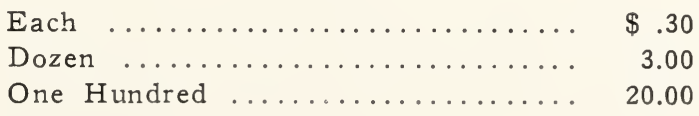




\section{BEARDED IRIS}

THERE are from one hundred and fifty to two hundred varieties of Iris in cultivation. Many of them are inferior; others are practically duplicates of some equally as good; therefore we have limited our list to nineteen varieties-all of distinct merit. We do not particularly recommend any of these named sorts, as they are all of about equal value. True enough, some of them cost more than others, and the prices may be somewhat of a guide to the decorative value of the varieties. At least, the higher priced varieties are the newer or scarcer varieties. These new and improved Iris are fully equal to the orchid in beauty, even if they are more perishable.

Explanation: "F" signifies "falls" or drooping petals, and "S," "standards" or upright petals. A plant has one spike; a clump has from three to five spikes.

FAIRY-White, delicately bordered and suffused soft blue. Plant, 25 cents; Clump, 50 cents.

FLORENTINA-Syn. Silver King. Creamy white, finely flushed lavender. The flowers are quite fragrant and are produced early in the season. Fine for cutting. Plant, 25 cents; Clump, 50 cents.

FRO-S, deep gold; F, brilliant chestnut-brown. Plant, 50 cents; Clump, $\$ 1.00$.

HALFDAN-Creamy white. Large flowers of good substance. Plant, 50 cents; Clump, $\$ 1.00$.

IRIS KING-S, clear lemon-yellow; F, rich maroon, bordered yellow. Large flowers, brilliant. Plant, 50 cents; Clump, $\$ 1.00$.

JUNIATA-S and F, clean blue, deeper than Dalmatica. Tallest of the bearded Iris. Large, fragrant flowers. Plant, 50 cents; Clump, $\$ 1.00$.

KOCHII-S and F, rich claret-purple. Very desirable. Plant, 25 cents; Clump, 50 cents.

LOHENGRIN-S and F, uniform soft shade of cattleya rose. Large. Plant, 50 cents; Clump, $\$ 1.00$.

LORELY-S, light yellow; F, ultramarine, bordered with cream. Plant, 50 cents; Clump, 75 cents.

MONSIGNOR-S, rich satiny violet; F, velvety purple-crimson with lighter margin. Large flowers. Exquisite. Very late. Plant, $\$ 1.00$; Clump, $\$ 2.00$.

MRS. ALAN GRAY - Delicate, pale rose-mauve. Free bloomer; blooms twice. Wonderful. Plant, 75 cents; Clump, $\$ 1.50$.

MIDNIGHT-A rich deep purple. the finest in this color. Excellent cut flower. Plant, 50 cents; Clump, $\$ 1.00$.

MRS. H. DARWIN-White, upper part of falls reticulated gold and violet. Wonderful new hybrid. Plant, 25 cents; Clump, 50 cents.

NAVAJO-S, light bronzy yellow, shaded lavender; F, deep maroon, heavily veined white and yellow; stigmas yellow; deep orange beard. Large, exquisite. Plant, $\$ 1.00$; Clump, $\$ 2.00$.

NIFBELUNGEN-S, fawn-yellow; F, violet-purple on bronze. Very large. Plant, 50 cents; Clump, \$1.00. 
PALLIDA DALMATICA - S, lavender; F, clear, deep lavender. Flowers very large. Superb variety. 40 inches. Plant, 50 cents; Clump, \$1.00.

PALLIDA HER MAJESTY-Tall, S, soft rose; F, deeper rose, heavily veined. Plant, 25 cents; Clump, 50 cents.

PALLIDA MANDRALISCAE-Very tall, rich lavender purple, large and beautiful. Plant, 25 cents; Clump, 50 cents.

WALHALLA-S, lavender; F, wine-red. Large flower. Free bloomer. Plant, 50 cents; Clump, $\$ 1.00$.

\section{JAPANESE IRIS}

HE Japanese Iris begin blooming the middle of June and continue blooming until the first of August.

Key No.

4 YOMO-NO-UMI. A fine free-flowering creamy white, 6 petals.

12 SHIPPO. Light lilac, densely veined with purple, 3 petals.

22 SANO-WATASHI. Huge flowers, white petals, gold in center.

31 RINHO. A rich lively purple, 6 petals.

44 YOSHIMO. Creamy-white delicately veined violet, 6 petals.

47 RENJO-NO-TOMA. Light violet with white veinings, 6 petals.

55 SHUCHIUKWA. Crimson-purple, with large white veins and center.

67 KIFAN-NO-MISAC. Pure snow white.

71 GEI-SHO-I. Bright crimson-purple with white veins and small white halo.

72 UJI-NO-HOTARU. Dark purple, shaded blue, late variety.

73 SHIRATAKI. Fine light parma-violet.

83 WASHI-NO-WO. Violet-purple.

94 KOMOCHI-GUMA. Rich, velvety pansy violet.

103 SAGAMI. Rich royal purple, 3 petals.

105 NAGANO. Rich violet-purple, shaded with blue, 6 petals.

107 TOKYO. Finest pure white.

109 HOSOKAWA. Rich purple with white veinings.

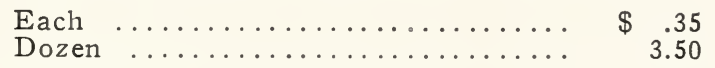

IBERIAN IRIS (Snow Queen). Blooms shortly after the Bearded Iris and are finished before the Japanese come in. An exceedingly valuable variety. Splendid cut flower sort.

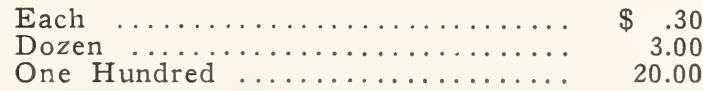




\section{CHINESE PEONIES}

ALBATRE. New, large white, late; an excellent sort. $\$ 2.00$ each.

ALBERT CROUSSE. Large, full, salmon-pink, fragrant, late. $\$ 2.00$ each.

ARMANDINE MECHIN. Flowers large, rather flat, very dark violet crimson. $\$ 1.50$ each.

BARONESS SCHROEDER. Large, opening flesh white and soon turning milk white, fragrant. Midseason. $\$ 2.00$ each.

DELACHEI. Rosy magenta. Extra good quality. $\$ 1.50$ each.

DUC DE WELLINGTON. Large. White guards with sulphur center. Fragrant. 50 cents each.

DUCHESS DE NEMOURS. Sulphur-white, medium. Fragrant. Early. 75 cents each.

DUCHESS DE CAZES. Rose pink, prolific bloomer. $\$ 1.00$ each.

EDUARD ANDRE. Crimson, large flowers, brilliant color. $\$ 1.00$ each.

EUGENE VERDIER. Large, pale hydrangea pink. Fragrant, dwarf habit. Late. $\$ 1.50$ each.

EUGENIE VERDIER. Large, pale hydrangea pink. Collar lighter; center deeper, flecked crimson. Fragrant. Tall. Midseason. $\$ 1.50$ each.

FELIX CROUSSE. Large, brilliant red, very fragrant. Late. $\$ 1.00$ each.

FESTIVA MAXIMA. Very large, pure white with crimson flecks. Tall. Early. \$1.00 each.

FIDELINA. American Beauty Rose, red, extra choice. Large flowers. Tall. $\$ 1.00$ each.

GRANDIFLORA ROSEA. Very large. Silvery pink. Very fragrant. Tall. Late. $\$ 1.00$ each.

INDEPENDENCE. White, full fragrant. 75 cents each.

JAMES KELWAY. Very large rose-white flower, changing to milkwhite. Tall. Early midseason. \$2.50 each.

MARIE CROUSSE. Very large, full, delicate shell pink with salmon tints. Tall, very fragrant. Midseason. \$3.00 each.

MARIE LEMOINE. Large. Pure white with cream-white center and occasional carmine tip. Very late. $\$ 1.00$ each. 
MME. CALOT. Very large. Flesh-pink, with center shaded darker. Very fragrant. Tall, very early. $\$ 1.00$ each.

MONS. JULES ELIE. Very large, deep shell-pink. The collar is lighter and shaded amber-yellow at the base. Very fragrant. Medium height. $\$ 1.50$ each.

MONS. MARTIN CAHUZAC. Medium, very dark purple garnet, with black reflex. Early midseason. \$5.00 each.

PRESIDENT TAFT. Pale pink collarette. Crown type, pink and gold; very fine. $\$ 1.50$ each.

SARAH BERNHARDT Large, apple-blossom pink, with each petal silver tipped. Very fragrant. Late midseason. $\$ 5.00$ each.

SOLANGE. Very large, full. Outer petals are a very delicate lilacwhite, deepening toward the center with salmon shading. One of the best. Very late. $\$ 10.00$ each.

SOLFATARE. Large. Milk white guards and sulphur collar, fading to sulphur white. Fragrant. Midseason. $\$ 1.00$ each.

THERESE. Very large, beautiful soft pink with a glossy reflex. One of the very best. Midseason. $\$ 6.00$ each.

TOURANGELLE. Large, flesh-pink, tinged with salmon. Midseason. $\$ 7.50$ each.

ZOE CALOT. Deep bluish pink. Medium size. Early. \$1.00 each.

\section{JAPANESE PEONIES}

JAPANESE PEONIES in large assortment, fragrant, of good size, but not generally large, particularly noted for the exquisite form and coloring, as a decorative note arranged singly or at most three to a vase, they are easily the most artistic of all the peonies. 3 to 5 -eye divisions, $\$ 1.50$ each; $\$ 12.00$ per dozen.

THE BEST PLANTING SEASON is September to December. The plant should be placed so that not over three inches of soil cover the topmost buds; no fresh manure may be used-only well rotted material; if this is not available, use bone meal and a fresh manure top dressing; fresh cow or sheep manure may be used under the plant, if not in contact with the roots. Winter protection is not needed, but a good covering of cow manure should be used annually for best results. 


\section{FERTILIZERS}

GROUND BONE-For lawns and general use.

25 pounds (delivered) ........... $\$ 1.50$

100 pounds " $\quad \ldots \ldots \ldots \ldots \ldots \ldots .4 .00$

200 pounds " $\quad \ldots \ldots \ldots \ldots \ldots \ldots . \ldots \ldots$

I 2 Ton “ $\quad \ldots \ldots \ldots \ldots \ldots \ldots . \ldots 32.50$

1 Ton " $\ldots \ldots \ldots \ldots \ldots . \ldots 60.00$

COW MANURE-Shredded and dried.

100 pounds (delivered) ............ $\$ 3.50$

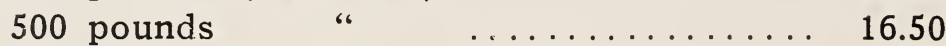

I 2 Ton $\quad$ " $\quad \ldots \ldots \ldots \ldots \ldots \ldots, 32.00$

1 Ton " $\quad \ldots \ldots \ldots \ldots \ldots .60 .00$

RAW COW MANURE.

1 Ton (delivered) ............ \$10.00

3 Tons " $\quad \ldots \ldots \ldots \ldots \ldots \ldots 25.00$

SHEEP MANURE-Pulverized, Standard Grade.

100 pounds (delivered) ............ $\$ 3.50$

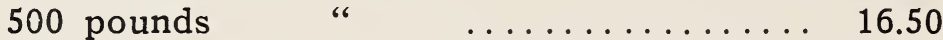

I $/ 2$ Ton " $\quad \ldots \ldots \ldots \ldots \ldots \ldots 32.00$

1 Ton " $\quad \ldots \ldots \ldots \ldots \ldots \ldots 60.00$

SHEEP MANURE-“Garden" special. Sheep dung removed from the sheared wool in process of manufacture into yarns. At least same value as the Standard Grade, but sold at a price based on cost, not on value.

100 pounds (delivered) ........... $\$ 2.75$

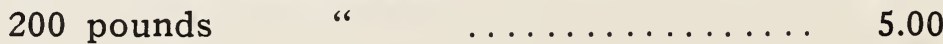

500 pounds “ $\quad \ldots \ldots \ldots \ldots \ldots \ldots . \ldots 10.00$

I/2 Ton " " $\quad \ldots \ldots \ldots \ldots \ldots \ldots 18.00$

1 Ton " $\quad \ldots \ldots \ldots \ldots \ldots \ldots 35.00$

(200 pounds will cover 600 square feet or more) 


\section{CONDITIONS OF ORDER}

THE PRICES in this Catalog do not cover extra choice specimens selected by customers in the Nurseries.

ALI PACKING CHARGES are included in our list prices, with the exception of specimen trees, for which packing is done at cost.

AS JAPANESE WEEPING CHERRIES are difficult to pack for shipment, packing charges are extra on all sizes.

FREE DELIVERY of orders within 10 miles of our Nurseries.

WHILE WE CARRY IN STOCK in our nurseries a complete line, we catalogue only a few specialties. We shall be pleased to quote you on any nursery stock you may want which is not mentioned herein.

TERMS-We give $2 \%$ discount for cash with order for plants. Cash with order, except to persons who satisfy us as to their responsibility, when accounts will be due in 30 days. We charge interest at $6 \%$ per annum.

CLAIMS-To receive consideration must be made within 10 days after receipt of goods.

SHIPPING INSTRUCTIONS-Shipping season opens about March 1st in the Spring, and August 1st in the Fall. Our stock is regularly inspected and certificate will be sent with each shipment. Write plainly and give explicit directions as to address and mode of shipment. Shipments will be forwarded exactly as directed; but when without instructions we will use our best judgment and forward by shortest and safest route. 

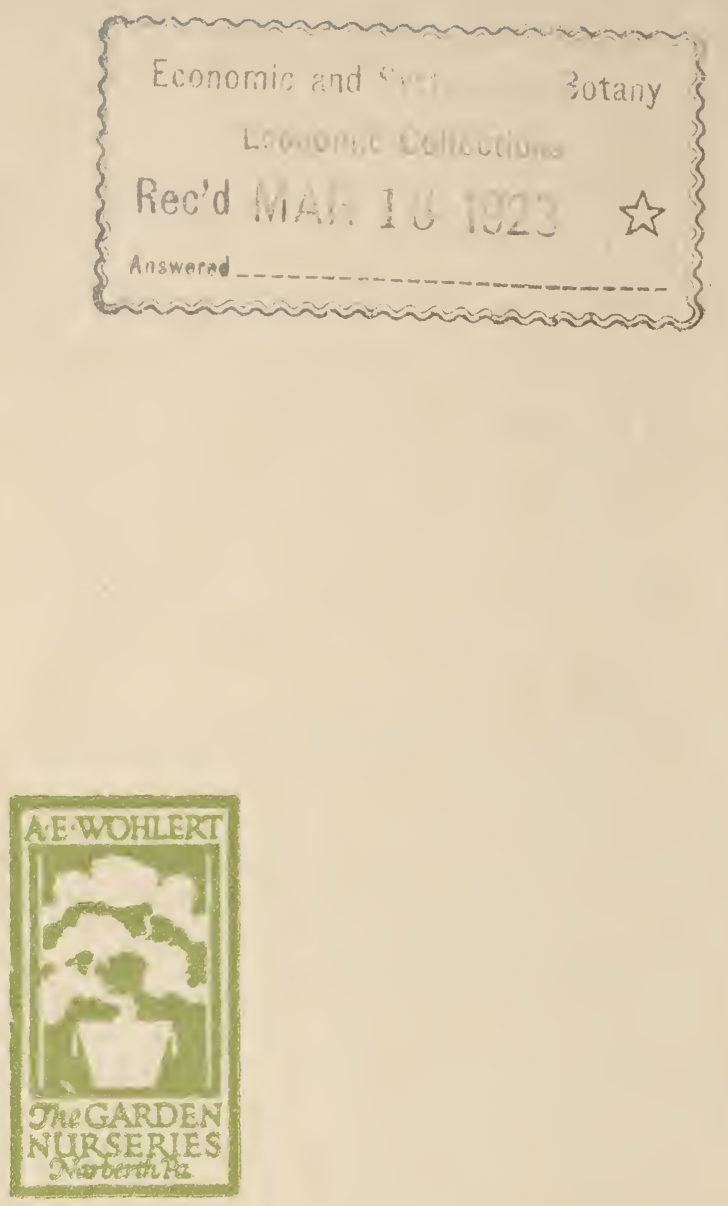